・综述・

\title{
黄河流域淡水鱼类多样性和保护
}

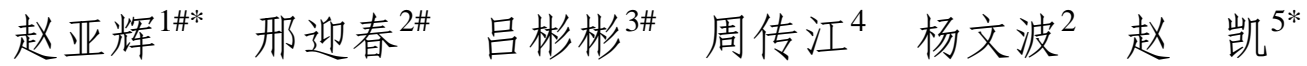 \\ 1 (中国科学院动物研究所, 中国科学院动物进化与系统学重点实验室, 北京 100101) \\ 2 (中国水产科学研究院资源与环境研究中心, 北京 100141) \\ 3 (陕西格林维泽环保技术服务有限公司, 西安 710075) \\ 4 (河南师范大学水产学院, 河南新乡 453007) \\ 5 (中国科学院西北高原生物研究所, 西宁 810008)
}

摘要: 本文介绍了黄河流域鱼类研究的历史、淡水鱼类的物种组成、整体分布格局、特有性、濒危性, 以及鱼类 多样性在黄河上、中、下游等的特点。历史上对于黄河鱼类多样性的研究, 历经了四个阶段, 从最初的零星记录 一直到现阶段的深入研究。综合历史记录和野外调查, 已知黄河流域分布的淡水鱼类共计 147 种, 隶属于 12 目 21 科 78属, 其中鲤形目种类占据绝对优势。另外, 全流域黄河特有种计有 27 种, 受危物种 24 种, 分别占总数的 $18.37 \%$ 和 $16.32 \%$ 。同中国主要江河相比, 黄河鱼类在高级分类阶元上的多样性较高, 但物种多样性则处在较低水平; 尽管 黄河特有鱼类和受危物种比例低于全国平均水平，但上游特有鱼类和珍稀濒危鱼类的占比很高。目前黄河鱼类多 样性大幅降低, 现状调查仅能采获历史记录种类的 $53.06 \%$ 。梯级水电开发、水资源过度利用、外来物种、水域污 染和过度捕捞都是威胁鱼类多样性的重要因素, 但对各河段和支流的影响不一, 应做出有针对性的保护部署。

关键词: 黄河; 可持续发展; 淡水鱼类; 中国特有种; 濒危物种

\section{Species diversity and conservation of freshwater fishes in the Yellow River basin}

\author{
Yahui Zhao ${ }^{1 \#^{*}}$, Yingchun Xing ${ }^{2 \#}$, Binbin Lü ${ }^{3 \#}$, Chuanjiang Zhou ${ }^{4}$, Wenbo Yang ${ }^{2}$, Kai Zhao ${ }^{*}$ \\ 1 Key Laboratory of Zoological Systematics and Evolution, Institute of Zoology, Chinese Academy of Sciences, Beijing \\ 100101 \\ 2 Research Center for Resources and Environment Protection, Chinese Academy of Fishery Sciences, Beijing 100141 \\ 3 Shaanxi Green Wiser Environmental Protection Technology Co. Ltd., Xi'an 710075 \\ 4 College of Fisheries, Henan Normal University, Xinxiang, Henan 453007 \\ 5 Northwest Institute of Plateau Biology, Chinese Academy of Sciences, Xining 810008
}

\begin{abstract}
This paper firstly reviews the research history on fish taxonomy and species diversity of the Yellow River basin. It includes four stages from the beginning of a few records on fish distributed in the river to now with deep studies covering biodiversity, zoogeography, phylogeny, and conservation. Based on the research literatures, museum database and records, and our own field surveys in the past 15 years throughout the entire basin, we discuss the species richness, distribution pattern, endemism, and threatened species of the freshwater fishes in the Yellow River basin. A total of 147 species, belonging to 78 genera, 21 families, and 12 orders, are distributed in the Yellow River. Among them, fishes from the order Cypriniformes are dominant. There are 27 endemic species to the river and 24 threatened species, accounting for 18.37\% and $16.32 \%$ of the total number of freshwater fish species of the river, respectively. Moreover, species diversity varied among the upper, middle, and lower reaches of the Yellow River. Comparing to other major rivers in China, the species richness is at a lower level although the diversity at higher taxon levels is relatively high. Proportions of endemic and threatened species of the Yellow River are lower than the average level of the
\end{abstract}

收稿日期: 2020-07-07; 接受日期: 2020-08-15

基金项目: 生态环境部生物多样性调查评估项目(2019HJ2096001006)、中国生物多样性监测与研究网络-内陆水体鱼类多样性监测专项网、青海省自 然科学基金项目(2020-ZJ-912)

*共同通讯作者 Co-author for correspondence. E-mail: zhaoyh@ioz.ac.cn; zhaokai@nwipb.cas.cn 
entire nation. However, the upper reach has large proportions of both endemic and threatened species, which should be drawn more attention for future conservation. At present, the species diversity of freshwater fish is rapidly decreasing. Our thorough field investigations may collect only $53.06 \%$ of the total species. Cascade hydropower development, over-exploitation of water resources, invasive species, water pollution, and overfishing are major threats to the fish species of the Yellow River. The main stream and tributaries may face different threat that need targeted strategies for the conservation of freshwater fishes in the future.

Key words: Yellow River; sustainable development; freshwater fishes; endemic species; threatened species

黄河是少数跨越我国三大地形阶梯的河流, 为 中国第二长河。作为中华文明的发源地之一, 从古 至今, 黄河在中国经济社会发展和生态安全方面均 具有十分重要的地位。黄河流域生态保护和高质量 发展已经上升为重大国家战略, 鱼类作为水生生态 系统的重要组成部分, 在过去很长一段时间里受到 人类经济社会发展的影响而发生了较大变化, 因此 从流域层面对黄河鱼类多样性组成进行系统总结 和回顾, 可为未来进行更有针对性的保护和恢复提 供科学依据。

\section{黄河流域的水系概况和发育历史}

黄河发源于青海省曲麻莱县麻多乡郭洋村巴 颜喀拉山北麓的约古宗列盆地, 流经鄂尔多斯高 原、黄土高原和黄淮海平原, 最后注入渤海(尤联元 和杨景春, 2013; 蔡建元, 2017)。黄河干流河道全长 $5,464 \mathrm{~km}$, 流域面积79.47万 $\mathrm{km}^{2}$ (陆孝平和富曾慈, 2010)。由于黄河每年夹带大量泥沙进入河口地区, 河道长度和流域面积也在不断扩大，2010-2012年 第一次全国水利普查(标准时点2011年12月31日)结 果显示, 黄河干流全长为5,687 $\mathrm{km}$, 流域面积为 81.31 万 $\mathrm{km}^{2}$ 。黄河流域总流域面积超过 $50 \mathrm{~km}^{2}$ 的河 流共计4,157条, 包括山地河流4,013条, 平原河流 114 条; 其中流域面积大于 $10,000 \mathrm{~km}^{2}$ 的支流共有 16 条(蔡建元, 2017)。

根据水沙特性、地形和地质条件, 黄河干流分 为上、中、下游。上游从河源到内蒙古自治区托克 托县河口村, 河道长 $3,471.6 \mathrm{~km}$; 其中黄河干流青 海省玛多县以上属河源段。中游从托克托县河口村 至河南省郑州附近的桃花峪, 河道长1,206 km, 其 中河口村至禹门口为峡谷河段, 两岸支流众多。下 游自桃花峪至河口, 河道长786.6 km, 其中利津以 下为黄河河口段(陆孝平和富曾慈, 2010)。流域内较 重要的一级支流包括洮河、湟水-大通河、祖厉河、
清水河、乌加河、大黑河、无定河、汾河、渭河、 洛河、沈河等。主要的湖泊有鄂陵湖、扎陵湖、乌 梁素海、盐池、红碱淖、沙湖、岗纳格玛错、阿涌 贡玛、星海湖、尔海湖等(蔡建元, 2017)。这些复杂 的干支流形态和生境的多样性, 奠定了黄河鱼类多 样性的发育基础。

黄河流域地势差别很大, 自西向东逐渐降低。 第一阶梯为青藏高原, 海拔在 $4,000 \mathrm{~m}$ 以上, 北部祁 连山是与内蒙古高原的分界; 第二阶梯大致以太行 山为东界, 海拔为 $1,000-2,000 \mathrm{~m}$; 第三阶梯由太行 山系以东至滨海, 东部海拔一般在 $500 \mathrm{~m}$ 以下(王文 杰等, 2017)。黄河总落差 $4,448 \mathrm{~m}$, 河源区大部流行 于青藏高原面上，河道迂回曲折、河水清浅、多湖 泊沼泽, 随后切过祁连山向东的余脉, 形成峡谷和 川地相间分布的形式，水流湍急，水头总落差达 1,300 m以上(吕拉昌和李文翎, 2012); 河源区比降 为 $1.2 \%$, 多石峡以下至托克托县的黄河上游区的 比降为 $1.5 \%$ (许畑心等, 2013)。因此, 黄河上游蕴藏 了大量水能资源, 是中国13个大型水电基地之一 (蒋立哲和王慧芳, 2011)。中游上段由北向南穿行于 晋陕峡谷之中, 河长虽然只有 $725 \mathrm{~km}$, 水头落差却 达到607 m; 随后河水冲出禹门口, 进入汾渭盆地, 接纳了汾、泾、渭、洛等支流，水量大增且夹带大 量泥沙, 河道很不稳定, 主流摆动频繁。中游两岸 大部分为黄土高原, 是黄河泥沙的主要来源地(许 昫心等, 2013)。下游穿行于黄淮海平原, 总落差约 为 $93 \mathrm{~m}$, 平均约为 $0.12 \%$, 河道高悬于地面之上, 洪水威胁较大(王文杰等, 2017)。

黄河流域的地貌格局奠定于燕山运动, 流域西 高东低的地貌轮廓产生于喜马拉雅运动第二幕(许 昫心等, 2013)。古黄河形成的时间不晚于上新世初 期, 当时各内陆水系相互串联贯通, 东流入海(李荣 全, 1988)。上新世末至早更新世初期, 受青藏高原 隆起的影响, 古黄河中游被湖泊分割, 原贯通入海 
的古黄河消失。现今黄河是第四纪古湖消亡之后在 古黄河故道基础上再次出现的河流(李荣全, 1993)。 研究显示, 黄河完全切穿三门峡古湖, 贯通东流入 海的时间大约为15万年前(王苏民等, 2001)。而黄 河 河口则随着黄河大规模南北迁移摆动而变迁, 在渤 海湾和苏北海岸都形成了不同规模的三角洲，中全 新世以后, 海平面不断下降, 海岸线逐渐退到现在 的位置(张兰生等, 2012)。全新世期间, 黄河除 9.6-8.5 ka BP和1,128-1,855 AD两度从苏北流入黄 海之外, 其余时间均流向东北入渤海(张兰生等, 2012)。黄河这样的发育历史也深刻影响了黄河鱼类 多样性的形成。例如河套地区鱼类组成与汾渭平原 有很大差异, 就与黄河发育的不同阶段有关(李思 忠, 1981)。

\section{2 黄河鱼类多样性的研究简史}

\section{1 国外博物学家考察记录阶段(1874-1931)}

1874年, 法国鱼类学家Sauvage Henri Émile和 Dabry de Thiersant描述了采自山西的细尾条鳅( Ne machilus bipartitus, 现归并为北方泥鳅Misgurnus mohoity) (Sauvage \& Dabry de Thiersant, 1874), 揭开了以现代科学方法研究黄河鱼类的序幕。随后 一批西方博物学家先后报道了黄河上游(Herzenstei n, 1888; Günther, 1898)、中游(Pappenheim, 1908; Nichols, 1925，1926)、下游(Mori，1928，1929; Fo wler, 1931)的鱼类。这一阶段的特点是研究比较零 散, 以描记鱼类新物种及物种记录为主, 且全部是 由国外科学家完成的。

\section{2 中国学者研究的初始阶段(1932-1958)}

20世纪30年代, 一批受西方现代科学训练的学 者陆续回国, 对中国鱼类开始进行调查和研究。以 张春霖1932年发表的A New Fish From Kaifeng为标 志(Tchang, 1932a), 黄河鱼类研究开始进入了以中 国学者为主导的时代。同年张春霖还报道了采自开 封的鱼类约25种(Tchang, 1932b)。1933年, 张春霖在 《中国鲤类志》中进一步记载黄河流域(中、下游) 鱼类约40种(Tchang, 1933)。傅桐生和张春霖在1933 年记录开封鱼类8科25属30种(Fu \& Tchang, 1933)。 傅桐生 1934 年记录河南辉县产鱼类约 38 种 $(\mathrm{Fu}$, 1934)。方炳文1935年报道了产于西宁的巴氏条鳅 (Nemachilus pappenheimi, 现为黄河高原鳅 Triplophysa pappenheimi) (Fang, 1935)。日本学者森
为三同期在黄河中、下游一带也做了大量调查工作 (Mori, 1936)。然而随着抗日战争全面爆发, 调查研 究工作也陷于停滞, 只有一些零星报道, 其中张春 霖1941年记录河南境内黄河鱼类约54种(Tchang, 1941)。受当时研究状况和交通条件限制，上述这些 调查研究工作主要集中于黄河中、下游地区，对于 上、中游的一些重要河流(如渭河等)基本都没有覆 盖。中华人民共和国成立以后，王香亭等(1956)对兰 州附近分布的包括黄河高原鳅 (Triplophysa pappenheimi)、黄河裸裂尻鱼(Schizopygopsis pylzovi) 等在内的约18种鱼类进行了详细记录。

这一阶段对于黄河流域鱼类的研究仍以分类 描述和物种记录为主，研究区域主要集中于黄河 中、下游地区，尽管收集的信息较之前已有很大进 步, 但尚不成系统, 还未从流域的角度进行整合。

\section{3 系统研究阶段(1959-1986)}

20世纪50年代，中国科学院动物研究所对黄河 干流及其附属水体进行了渔业生物学基础调查, 完 成了《黄河渔业生物学基础初步调查报告》(中国科 学院动物研究所鱼类组与无脊椎动物组, 1959), 标 志着黄河鱼类研究进入了全流域大尺度阶段。之后 中国科学院动物研究所李思忠发表了《黄河鱼类区 系探讨》(李思忠, 1965), 文中全面记载鱼类14目27 科96属153种，同时还首次从动物地理的角度探讨 了黄河鱼类区系的组成。1981-1983年，原国家水产 总局组织了“黄河水系渔业资源调查”，在调查结果 的基础上出版了《黄河水系渔业资源》一书，书中 记录了鱼类191种或亚种，隶属于15目32科116属 (何志辉和谢祚浑, 1986)。

除全流域研究外, 对于一些重要支流也有调 查。例如山西师范学院生物系(1960)发表了《汾河 渔业生物学基础调查》; 黄洪富等(1965)在《渭河 中段鱼类调查研究》中记载了38种(亚种)鱼类; 宋 世良和王香亭(1983)对渭河上游鱼类进行了调查, 报道鱼类23种。此外，一些区域性鱼类调查也覆盖 了黄河流域相关地区。例如曹文宣和邓中麟(1962)、 曹文宣和伍献文(1962)对四川西部鱼类的研究过程 中，记述了黄河上游分布的一批裂腹鱼亚科和高原 鱾属(Triplophysa)的种类; 赵肯堂(1963)报道了内蒙 古呼和浩特鱼类15种; 武云飞和陈瑗(1979)记录青 海省果洛和玉树地区(包括上游的扎陵湖和鄂陵湖) 鱼类28种，含3新种和1新亚种；1979-1980年，甘肃 
省农业科学院水产研究所对黄河玛曲段鱼类资源 进行了初步调查(刘阳光, 1981)；1980-1983年, 内 蒙古自治区水产研究所和南开大学生物系对乌梁 素海、哈素海及黄河干流内蒙古段进行了渔业资源 综合调查(旭日干, 2013)。

本阶段对于黄河流域鱼类的研究已经站到了 流域层面, 从黄河上游到河口对全流域的鱼类多样 性进行了系统总结, 使得我们第一次对黄河流域的 鱼类区系组成有了一个全面的认识。

\section{4 扩展研究阶段(1987年至今)}

这一阶段的研究工作, 以1987年出版的《秦岭 鱼类志》(陕西省动物研究所等, 1987)和1989年出版 的《青海经济动物志: 鱼纲》(武云飞和吴翠珍, 1989) 为标志, 逐渐辐射和扩展到流域内的各行政省区和 重要地理区, 认识范围和深度进一步扩大。《秦岭鱼 类志》围绕中国重要的南北分界线秦岭, 对其鱼类 多样性及分布进行了详细探讨, 书中记述了黄河流 域鱼类99种和亚种, 同时还和相邻的长江水系进行 了对比, 成为重要地理区鱼类多样性研究的代表。 而《青海经济动物志: 鱼纲》则是青海第一部系统 性的鱼类志。这些著作对各行政区划内黄河流域鱼 类进行了分类订正和详细记录, 为现今研究流域鱼 类多样性变化提供了重要的历史本底记录。后来又 相继有《四川鱼类志》(丁瑞华，1994)、《山东鱼类 志》(成庆泰和周才武, 1997)、《内蒙古动物志: 圆 口纲、鱼纲》(旭日干, 2013)、《黄河流域鱼类图志》 (蔡文仙等, 2013)、《黄河鱼类志》(李思忠, 2015)、 《黄河陕西段渔业资源评价》(王丰和沈红保, 2020) 等著作出版, 这些都成为研究黄河鱼类的重要参考 资料。

近年来应用生物多样性、群落结构和生物完整 性等方法对黄河鱼类进行多样性分析的工作也不 断涌现, 从黄河上游(李柯禁等, 2012; 申志新等, 2014)、中游(王益昌等, 2017; 林鹏程等, 2019a; 沈 红保等, 2019)、下游 (杨柏贺等, 2019)到黄河口(王娇 等, 2018)的不同河段的鱼类多样性基本都有涵盖。 另外从遗传多样性的角度探讨不同种类种群分化、 物种演化和动物地理(Duan et al, 2009; 张艳萍等, 2013), 使得对黄河鱼类多样性的研究走向纵深。

黄河鱼类多样性的研究经历了从“认识-了解总结-深入”的阶段, 同时针对黄河流域人类社会经 济发展对于鱼类资源的影响也有一定程度的探讨
(唐文家等，2006；李芳等，2008；权全等，2018；王 丰, 2020)。但如果从全国层面来看, 与长江和珠江 流域鱼类研究相比, 目前对于黄河流域鱼类多样性 的认识在广度和深度上还有明显不足。面对黄河流 域生态保护和高质量发展的要求, 还有大量的基础 工作需要完成。

\section{黄河鱼类的多样性}

\section{1 鱼类多样性组成}

综合历史标本采集记录、已发表的各类文献， 以及作者多年在黄河流域开展调查工作的结果，对 黄河流域自然分布的鱼类进行统计，并对同物异名 等分类学问题进行了订正后，对黄河流域自然分布 的鱼类进行统计，并对同物异名等分类学问题进行 了订正。涵盖的物种包括纯淡水生活的种类，以及 江海洄游鱼类。广盐性适应的河口鱼类不计入, 有 些古籍中或引述他人研究而未有明确标本记录的 物种亦未计入。

总结得出：黄河(含干流、支流及附属湖泊)共 有土著鱼类147种，隶属于12目21科78属。在目级组 成上, 鲤形目鱼类共有 115 种, 占到鱼类总种数的 $78 \%$ ，远远多于其他目; 鲇形目鱼类11种，占总数 的 $8 \%$; 鲈形目排在第三位，但也只有 8 种鱼类，占 总数的 $5 \%$; 其余各目的种类均不足 4 种，有 7 个目分 别只有1种鱼类(图1)。

在科级水平上, 鲤形目鲤科和条鳅科的鱼类最 多, 其中鲤科计有 86 种, 占黄河鱼类总种数的 $58.5 \%$ ，条鳅科 20 种，占总种数的 $13.6 \%$; 鲇形目的 魭科位居第三，共有 9 种，占总种数的 $6.1 \%$; 其余各 科鱼类数量均不足3种(图2)。鲤形目和鲤科鱼类是 黄河鱼类区系组成中最重要的组分，这与中国整体 上的淡水鱼类区系组成特点相吻合(张春光和赵亚 辉, 2016)。黄河鱼类在目级和科级水平表现出较高 的多样性，在中国内陆水体分布的土著鱼类共有 17 目，黄河拥有其中 12 目，占比为 $70.6 \%$; 而在中国淡 水鱼类的 47 个科中，黄河有 21 科，也占到了总数的 $44.7 \%$ 。

此外，在中国鲤科鱼类的 12 个亚科中，黄河流 域拥有其中的11个，只有适合暖水性生活的野鲮亚 科鱼类在黄河没有分布记录，因此在鲤科亚科层级 上的多样性也是比较高的。在这些亚科中，鮈亚科 


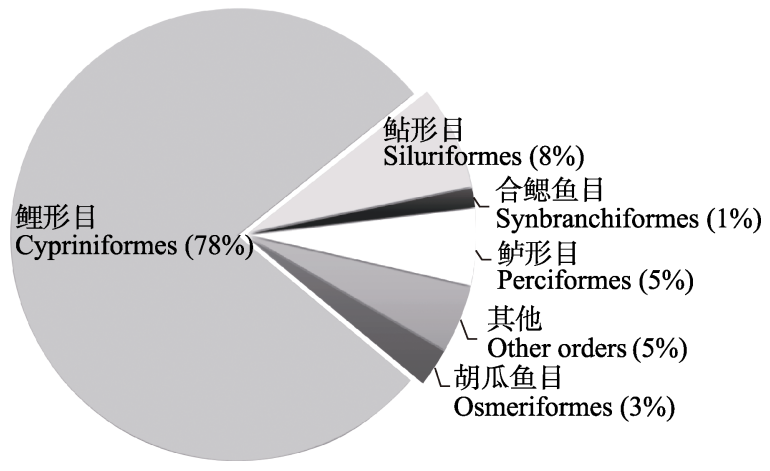

图1 黄河流域淡水鱼类目级组成。其他目包括鲟形目、鲑 形目、鳗鲭目、鲱形目、领针鱼目、刺鱼目、鲉形目。

Fig. 1 Freshwater-fish composition of the Yellow River in order level. Other orders include Acipenseriformes, Salmoniformes, Anguilliformes, Clupeiformes, Beloniformes, Gasterosteiformes, and Scorpaeniformes.
鱼类的占比最高，计有 30 种，占到黄河鲤科鱼类总 种数的 $34.8 \%$; 其次为雅罗鱼亚科和鲌亚科, 各有7 种, 分别占鲤科鱼类总种数的 $8.1 \%$ (图3)。

然而从物种数量上分析, 黄河分布的鱼类只占 到中国淡水鱼类总种数的 $8.9 \%$, 在中国七大主要水 系中只能排在第三位，远低于珠江和长江鱼类的数 量(表1)。秦岭-淮河是中国南北分界线，黄河在北方 的各主要水系中, 鱼类物种多样性是最高的(表1)。 然而如果考虑到流域面积的大小，则呈现出不同的 多样性格局。单位流域面积分布 $\left(\right.$ 万 $\left.\mathrm{km}^{2}\right)$ 的物种数量 以珠江为最高，达到11.06种，而黄河则只有1.95种, 在中国七大江河中排在倒数第二位，仅略高于黑龙 江的1.46种(表1)。

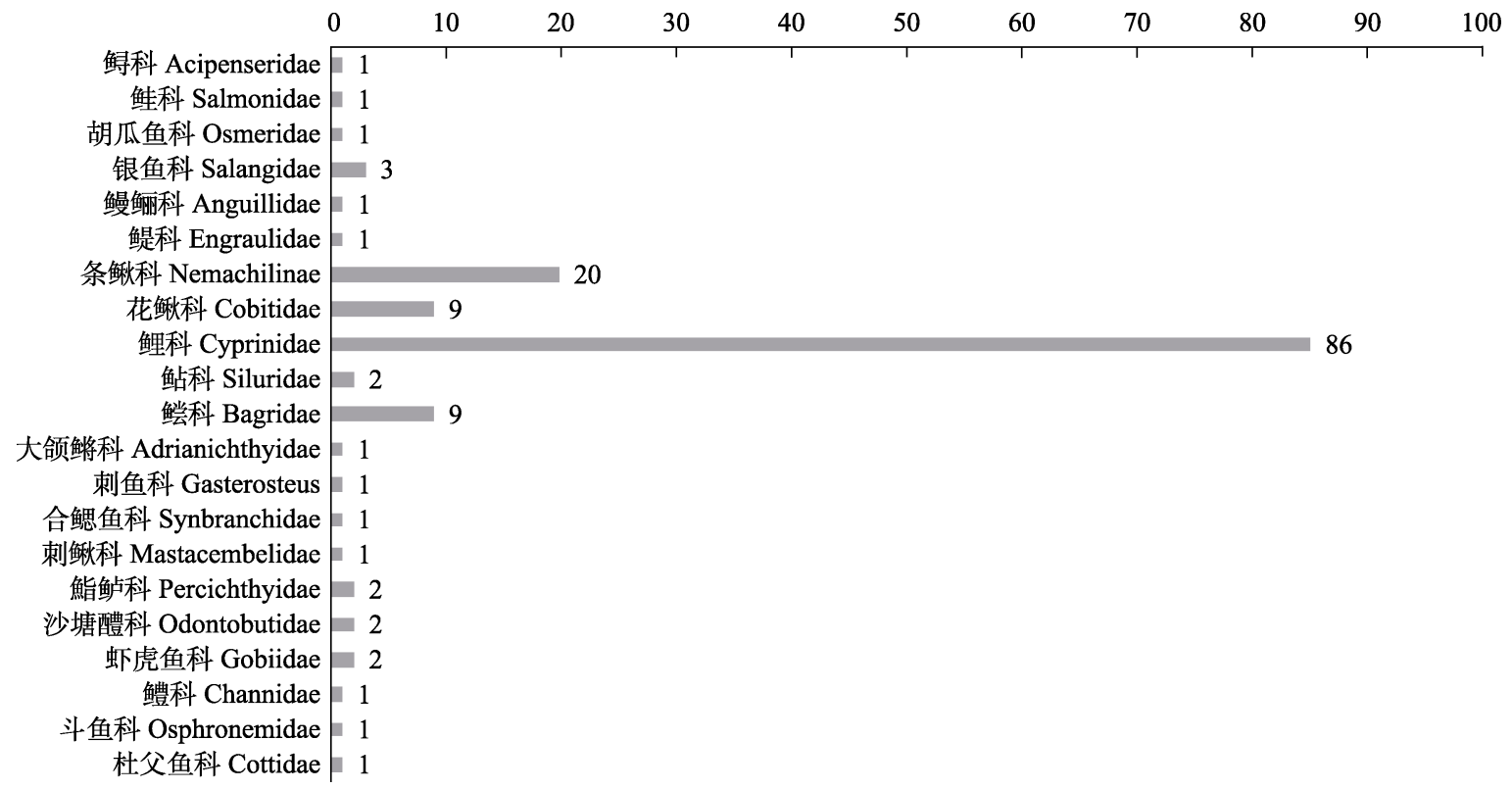

图2 黄河流域淡水鱼类科级组成

Fig. 2 Freshwater-fish composition of the Yellow River at family level

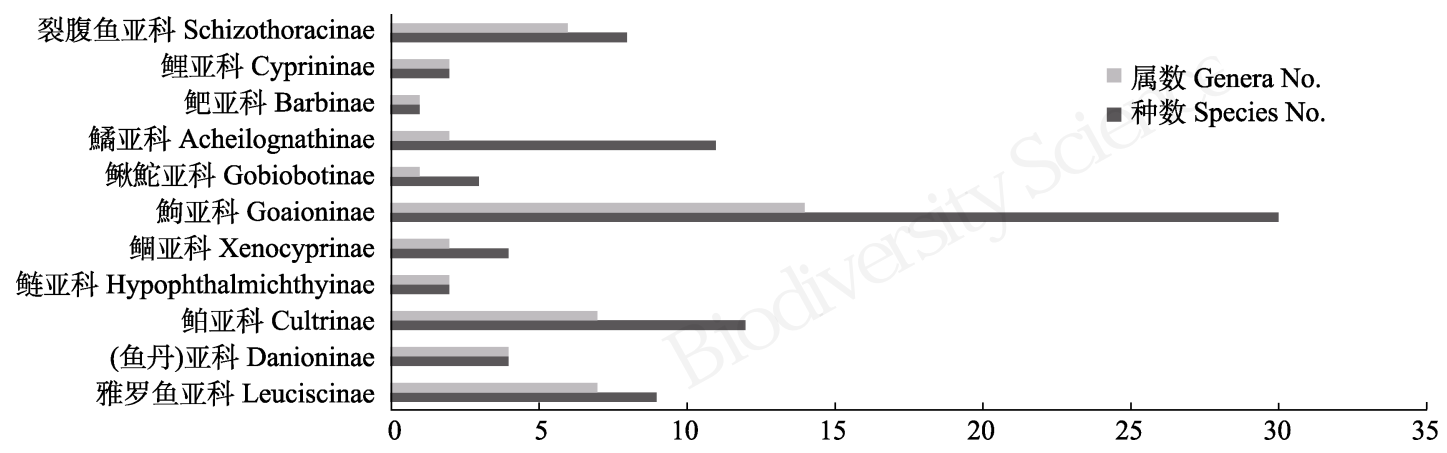

图3 黄河流域鲤科鱼类的亚科组成

Fig. 3 Cyprinid fish composition of the Yellow River at subfamily level 
表1 中国七大江河水系鱼类物种数量比较

Table 1 Comparison of species richness among seven major river basins in China

\begin{tabular}{|c|c|c|c|c|}
\hline $\begin{array}{l}\text { 水系 } \\
\text { River basins }\end{array}$ & $\begin{array}{l}\text { 种数 } \\
\text { Species no. }\end{array}$ & $\begin{array}{l}\text { 干流长度 } \\
\text { River length } \\
(\mathrm{km})\end{array}$ & $\begin{array}{l}\text { 流域面积 } \\
\text { Basin area } \\
\left(\times 10^{4} \mathrm{~km}^{2}\right)\end{array}$ & $\begin{array}{l}\text { 单位流域面积 } \\
\text { 物种数 } \\
\text { Species no. } \\
/ 10,000 \mathrm{~km}^{2}\end{array}$ \\
\hline $\begin{array}{l}\text { 黑龙江 } \\
\text { Heilongjiang } \\
\text { River }\end{array}$ & 132 & 1,899 & 90.24 & 1.46 \\
\hline $\begin{array}{l}\text { 辽河 } \\
\text { Liaohe River }\end{array}$ & 82 & 1,345 & 22.11 & 3.71 \\
\hline $\begin{array}{l}\text { 海河 } \\
\text { Haihe River }\end{array}$ & 83 & 1,090 & 26.55 & 3.13 \\
\hline $\begin{array}{l}\text { 黄河 } \\
\text { Yellow River }\end{array}$ & 147 & $5,463.6$ & 75.24 & 1.95 \\
\hline $\begin{array}{l}\text { 淮河 } \\
\text { Huaihe River }\end{array}$ & 113 & 1,000 & 19.12 & 5.91 \\
\hline $\begin{array}{l}\text { 长江 } \\
\text { Yangtze River }\end{array}$ & 405 & 6,300 & 180 & 2.25 \\
\hline $\begin{array}{l}\text { 珠江 } \\
\text { Pearl River }\end{array}$ & 489 & 2,214 & 44.2 & 11.06 \\
\hline
\end{tabular}

黑龙江、淮河、长江和珠江的鱼类数据来自于 $\mathrm{He}$ 等(2020), 辽河和 海河的鱼类数据来自于Xing等(2016); 干流长度和流域面积数据来 自于陆孝平和富曾慈(2010)。

Fish data of the Heilongjiang, Huaihe, Yangtze, and Pearl rivers were from He et al, 2020; fish data of the Liaohe and Haihe Rivers were from Xing et al, 2016. Data of river length and basin area were from $\mathrm{Lu}$ $\& \mathrm{Fu}(2010)$.

\section{2 特有种、珍稀濒危物种}

黄河分布有中国特有鱼类69种, 占流域物种总 数的 $46.9 \%$; 其中黄河特有种只有 27 种, 占黄河鱼 类总数的 $18.4 \%$ 。而珠江和长江的流域特有种数量
分别占到流域淡水鱼类总数的 $48.3 \%$ 和 $42.7 \%$ (He et al, 2020)。在黄河流域分布的特有种中，有些物种分 布区范围极其狭窄，例如郃阳高原鳅(Triplophysa heyangensis), 目前仅知分布于陕西合阳县一条流 入黄河的支流中(朱松泉, 1992)。因此这些物种的栖 居环境一旦受到人为活动的扰动，极易造成种群衰 竭而濒危。

根据2016年《中国脊椎动物红色名录》(蒋志刚 等，2016)，共有143种黄河鱼类被评估(表2)，其中 评估为极危 (CR) 的有 4 种, 濒危 $(\mathrm{EN})$ 的 10 种，易危 (Vulnerable, VU) 的10种，属于受威胁等级的物种合 计有 24 种, 占到所有鱼类总种数的 $16.3 \%$; 低于 $20.4 \%$ 的全国平均水平(曹亮等, 2016)。而评价为近 危(NT)和无危(LC)的分别有5种和 94 种, 两者合计 占到评估鱼类总数的 $69.2 \%$ 。数据缺乏(DD) 的有 20 种，占到评估总数的 $14.0 \%$ (蒋志刚等, 2016; 曹亮 等, 2016)。

在受威胁鱼类中属于黄河特有种的有 11 种，占 到受危胁鱼类总种数的 $45.8 \%$; 而在黄河特有鱼类 中，目前被评估为受威胁物种的占比则为 $40.7 \%$, 也就是说无论从哪个角度看, 黄河鱼类中既是黄河 特有种又同时受到严重威胁的物种比例是非常高 的。

表2 黄河流域濒危鱼类组成

Table 2 Composition of threatened fishes in the Yellow River basin

\begin{tabular}{|c|c|c|c|c|c|c|c|}
\hline & 极危 CR & 濒危 EN & 易危 VU & 近危 NT & 无危 LC & 数据缺乏 DD & 未评估 Unevaluated \\
\hline 上游 Upper reach & 2 & 6 & 8 & 2 & 19 & 5 & 0 \\
\hline 中游 Middle reach & 1 & 4 & 5 & 4 & 72 & 11 & 3 \\
\hline 下游 Lower reach & 2 & 3 & 1 & 1 & 78 & 13 & 2 \\
\hline 全流域 River basin & 4 & 10 & 10 & 5 & 94 & 20 & 4 \\
\hline
\end{tabular}

表3 黄河上、中、下游鱼类物种丰富度比较

Table 3 Comparison of species richness among the upper, middle and lower reaches of the Yellow River

\begin{tabular}{|c|c|c|c|c|c|c|c|c|}
\hline & $\begin{array}{l}\text { 目 } \\
\text { Order }\end{array}$ & $\begin{array}{l}\text { 科 } \\
\text { Family }\end{array}$ & $\begin{array}{l}\text { 鲤科中的亚科数量 } \\
\text { Subfamily in Cyprinidae }\end{array}$ & $\begin{array}{l}\text { 物种 } \\
\text { Species }\end{array}$ & $\begin{array}{l}\text { 干流河道长度 } \\
\text { River length } \\
(\mathrm{km})\end{array}$ & $\begin{array}{l}\text { 流域面积 } \\
\text { River basin } \\
\left(10,000 \mathrm{~km}^{2}\right)\end{array}$ & $\begin{array}{l}\text { 物种数量/1,000 km } \\
\text { 河长 } \\
\text { No. of species/per 1,000 } \\
\text { km river length }\end{array}$ & $\begin{array}{l}\text { 物种数量 } / 10,000 \mathrm{~km}^{2} \text { 流 } \\
\text { 域面积 } \\
\text { No. of species } / 10,000 \\
\mathrm{~km}^{2} \text { river basin }\end{array}$ \\
\hline $\begin{array}{l}\text { 上游 } \\
\text { Upper reach }\end{array}$ & 3 & 4 & 5 & 44 & $3,471.6$ & 42.82 & 12.67 & 1.03 \\
\hline $\begin{array}{l}\text { 中游 } \\
\text { Middle reach }\end{array}$ & 8 & 14 & 11 & 100 & 1,206 & 34.38 & 82.92 & 2.91 \\
\hline $\begin{array}{l}\text { 下游 } \\
\text { Lower reach }\end{array}$ & 11 & 20 & 10 & 101 & 786.6 & 2.27 & 128.40 & 44.49 \\
\hline $\begin{array}{l}\text { 全流域 } \\
\text { River basin }\end{array}$ & 12 & 21 & 11 & 147 & 5,464 & 79.47 & 26.90 & 1.85 \\
\hline
\end{tabular}




\section{3 黄河上、中、下游鱼类多样性的差异}

黄河上、中、下游在鱼类多样性、特有种、受 威胁物种的组成上也显示出不同的特点。从物种数 量上分析, 上、中、下游物种数量分别为 44 种、 100 种和101种(表3), 各占鱼类总数的 $29.9 \%$ 、68.0\%和 $68.7 \%$ 。

尽管黄河上游流域面积超过整个流域的一半, 达到了全流域面积的 53.9\% (陆孝平和富曾慈, 2010), 然而从鱼类物种丰富度上看, 上游鱼类数量 最少, 且物种组成也相对简单, 只有3个目(表3), 即 鲤形目、鲇形目和刺鱼目。其中刺鱼目只有一种, 即 中华多刺鱼(Pungitius sinensis), 主要分布在上游下 段的河套地区，大致从临河到托克托河段，以及乌 梁素海、哈素海等(旭日干, 2013); 而鲇形目物种数 量亦很少, 只有3种。故在黄河上游分布的鱼类主要 集中在鲤形目的少数类群中, 例如条鳅科高原鳅属 有 15 种, 鲤科裂腹鱼亚科有 7 种, 这两个类群的鱼 类就占到了上游鱼类总数的一半, 体现了典型的青 藏高原鱼类区系的特点。因此从物种丰富度和物种 组成上看, 黄河上游鱼类在高级分类阶元和物种层 级上, 均呈现出单调的多样性特征。

相反, 黄河中游和下游则表现出相对较高的多 样性。黄河中游的 100 种鱼类来自于 8 目 14 科, 而下 游的101种鱼类则来自于11目20科(表3)。如果考虑 到河流长度和流域面积, 则这种现象更为明显 (表 $3)$ 。中游虽然河道长度只有上游的大约 $1 / 3$, 但是两 岸支流众多, 特别是渭河, 是黄河最大的支流, 干 流全长 $830 \mathrm{~km}$, 流域面积达到了 13.48 万 $\mathrm{km}^{2}$, 占到 黄河中游整个流域面积的 $39.21 \%$ (陆孝平和富曾慈, 2010)。渭河很多支流发源于秦岭北麓, 生境多样, 因此也孕育了不少特有物种, 其中仅渭河流域陕西 段就记载有鱼类47种(沈红保等, 2019)。其他像汾河 (河流长度693.8 km)、无定 河(491.2 km)、沉河 (485.1 $\mathrm{km}$ )等都是汇入黄河中游(陆孝平和富曾慈, 2010)。 中游包括很多大型支流, 且生境较上游更加多样化, 是黄河中游鱼类多样性较高的重要原因。现代黄河 下游河道基本上限制在防洪大堤或大堤与山脚之 间, 流域面积 2.27 万 $\mathrm{km}^{2}$ (陆孝平和富曾慈, 2010), 因此下游单位面积内的鱼类物种数量远远大于上 游和中游(表3)。历史上黄河下游不断摆动, 特别是 发生了多次“夺淮入海”, 在黄河26次改道中, 有 15 次影响到淮河(许昫心等, 2013), 因此使得整个华北
平原的鱼类区系在各河系之间产生了充分交融, 这 也是黄河下游鱼类多样性较高的一个重要原因。

黄河上、中、下游在鱼类特有性和受威胁物种 方面也存在显著区别, 但恰恰与物种丰富度呈现相 反的格局。上游分布有黄河特有鱼类17种(表4), 主 要集中在鲤形目条鳅科的高原鳅属(6种)和鲤形目 鲤科的裂腹鱼亚科(4种)等, 占到上游鱼类种数的 $38.6 \%$ (表4), 亦即大约每5种上游鱼类中, 就有 2 种 为黄河特有。此外, 在这 17 种黄河特有鱼类中, 只 见于黄河上游的就有 10 种，包括黄河高原鳅、黄河 雅罗鱼 (Leuciscus chuanchicus)、骨唇黄河鱼 (Chuanchia labiosa) 等, 占到了全流域特有鱼类总 数的 $37.0 \%$ 。中游分布有黄河特有鱼类 16 种，占中游 所有鱼类的 $16.0 \%$ (表 4$)$; 其中只在中游分布的有 6 种，占流域特有鱼类的 $22.2 \%$ 。黄河上游和中游基本 穿行于中国地势上的第一和第二阶梯，自然环境与 下游相差较大, 微生境更加多样, 是造成上、中游 特有种类较多的原因之一。加之现代黄河形成比较 晚近，上、中游和下游在较长时间内处于相对隔绝 的格局，这是上、中游特有种较多的另外一个主要 原因。故只见于上、中游而不见于下游的黄河特有 鱼类合计就有 21 种，占全部特有鱼类的 $77.78 \%$ 。特 有鱼类这一分布特点，在未来进行全流域保护规划 时应该特别引起注意。

黄河上游分布有 16 种受威胁物种，占到上游物 种总数的 $36.4 \%$; 而中游和下游则分别有 10 种和 6 种 受威胁物种，占比分别为 $10.0 \%$ 和 $5.9 \%$, 均低于流 域平均水平(表4)。值得注意的是，在上游的这些受 威胁物种中，有 8 种是黄河上游特有的，占到上游 受威胁物种的一半。从另一角度看, 在 11 种黄河上 游特有鱼类中，有 $72.7 \%$ 的种类属于受威胁物种， 其中极危(CR) 1种, 濒危(EN) 5种，易危(VU) 2种。 因此黄河上游表现出了高特有性和高濒危性的鱼 类多样性特点, 这也是黄河流域生态大保护需要着 重考虑的。

黄河上、中、下游鱼类在物种组成、特有性、 濒危性，以及鱼类多样性现状特点总结如表5。

\section{4 黄河鱼类区系的形成}

现代黄河鱼类区系的形成，大体肇始于中新世， 这时鲃属(Barbus)、鲤属(Cyprinus)、雅罗鱼属 (Leuciscus) 等都已广泛分布于亚洲北部到欧洲之间 (李思忠, 2015)。至上新世时, 古黄河形成, 此时的 
表4 黄河上、中、下游鱼类特有种和受威胁物种比较

Table 4 Comparison of endemic and threatened fish species among the upper, middle and lower reaches of the Yellow River

\begin{tabular}{lllll}
\hline & $\begin{array}{l}\text { 黄河特有鱼类 } \\
\text { Endemic species }\end{array}$ & $\begin{array}{l}\text { 黄河特有鱼类百分比 } \\
\text { Percentage of endemic species (\%) }\end{array}$ & $\begin{array}{l}\text { 受威胁物种 } \\
\text { Threatened species }\end{array}$ & $\begin{array}{l}\text { 受威胁物种百分比 } \\
\% \text { of threatened species }\end{array}$ \\
\hline 上游 Upper reach & 17 & 38.6 & 16 & 36.4 \\
中游 Middle reach & 16 & 16.0 & 10 & 10.0 \\
下游 Lower reach & 5 & 5.0 & 6 & 5.9 \\
全流域 River basin & 27 & 18.4 & 24 & 16.3 \\
\hline
\end{tabular}

表5 黄河上、中、下游鱼类多样性特点

Table 5 Characters of fish diversity among the upper, middle and lower reaches of the Yellow River

\begin{tabular}{lllll}
\hline & $\begin{array}{l}\text { 鱼类物种组成 } \\
\text { Species composition }\end{array}$ & $\begin{array}{l}\text { 黄河特有鱼类占比 } \\
\text { Proportion of endemic species to } \\
\text { the Yellow River }\end{array}$ & $\begin{array}{l}\text { 受威胁物种占比 } \\
\text { Proportion of threatened species }\end{array}$ & $\begin{array}{l}\text { 鱼类多样性现状 } \\
\text { Current status of fish diversity }\end{array}$ \\
\hline 上游 Upper reach & 单调 Simple & 高 High & 高 High & 一般 Average \\
中游 Middle reach & 丰富 Rich & 较低 Relatively low & 较低 Relatively low & 较差 Relatively poor \\
下游 Lower reach & 丰富 Rich & 低 Low & 低 Low & 差 Poor \\
\hline
\end{tabular}

鱼类区系已经接近现代的样貌, 特别是在江河平原 区，很多都是现生属的种类。第四纪以来，现黄河 中游地区青鱼 (Mylopharyngodon piceus)、草鱼 (Ctenopharyngodon idellus)、鲢(Hypophthalmichthys molitrix)、鳙(Aristichthys nobilis)已很普遍(李思忠, 2015), 这与当时黄河中游被湖泊分割, 存在大水体 有关。现代黄河重新贯通后, 下游摆动剧烈, 因此 还吸纳了邻近河流和黄淮平原的一些种类, 最终形 成现今的黄河鱼类区系格局。

在生物地理区划上，黄河流域全部位于古北区， 但是却跨越了多个亚区或小区。黄河上游和中、下 游由于在地质历史上的差异, 其鱼类区系实际也有 各自的形成过程。黄河上游特别是河源区, 基本位 于青藏高原夷平面上, 鱼类以裂腹鱼亚科和高原鳅 属的种类为主, 这是伴随着上新世青藏高原的急剧 抬升而逐渐演化形成的。例如由原始鲃亚科特化而 成的裂腹鱼类向高原四周辐射, 并在黄河上游形成 一些特有属、种, 如黄河鱼属(Chuanchia)、扁咽齿 鱼属(Platypharodon), 以及花斑裸鲤(Gymnocypris eckloni eckloni)等。然而当古黄河贯通时, 上游区地 势已抬升至相当高度, 河道落差大, 因此黄河东部 的江河平原鱼类如鲌亚科、鱽亚科和鲢亚科等的种 类都未能进一步分布到河套地区(李思忠, 1981, 2015), 造成了现今黄河上游和中、下游地区在鱼类 区系组成上的差异。

\section{黄河鱼类现状}

本文部分作者自2007年以来对黄河流域干流 及主要支流等的调查显示, 目前黄河鱼类的多样性 衰退比较明显。多年调查中尚可以采集到的土著鱼 类约 78种，只占到全流域的 $53.1 \%$, 有几乎一半的 种类完全或部分从黄河流域主要水体消失。例如日 本学者森为三1928年曾在黄河下游采集到2尾达氏 鲟(Acipenser dabryanus)标本, 体长2,400-2,700 mm, 应为成熟个体(李思忠, 2015), 之后20世纪60年代有 采自烟台的标本, 但再无黄河的记录(李思忠, 1987)。李思 忠(1965, 1987, 2015)曾根据古文献记录, 认为黄河亦应分布有中华鲟(Acipenser sinensis)、鳇 (Huso dauricus)和白鲟(Psephurus gladius)等, 由于 没有确实的标本记录, 本文暂不将这些鱼类计入。 但仍可看出, 黄河流域在历史上可能是这些鱼类的 边缘分布区, 由于气候变化等因素使得这些鱼类不 见于现代黄河。然而鱼类多样性丧失的绝大部分发 生于近几十年, 且普遍发生于黄河的上、中、下游 以及干、支流。

2008年，对黄河干流(上、中、下游及河口)的 调查只发现49种淡水鱼类(茹辉军等, 2010)。 2009-2013年间对黄河龙羊峡以上干流及附属湖泊 (扎陵湖、鄂陵湖等)进行的调查显示, 只有 10 种上游 土著鱼类可以被采集到(申志新等, 2014)。而龙羊峡 
到刘家峡黄河干流，历史上至少分布有刺鮈 (Acanthogobio guentheri) 、厚唇裸重唇鱼 (Gymnodiptychus pachycheilus)、极边扁咽齿鱼 (Platypharodon extremus)、骨唇黄河鱼、黄河裸裂 尻鱼、花斑裸鲤(Gymnocypris eckloni eckloni)和似鲇 高原鳅(Triplophysa siluroides)等7种珍稀或特有鱼 类。根据近年的调查, 其中厚唇裸重唇鱼、极边扁 咽齿鱼、骨唇黄河鱼已经基本退出这一河段, 其分 布区进一步向上游退缩。在黄河中游, 2010-2012年 在山西段调查发现42种土著鱼类(赵瑞亮等, 2014)。 2013-2014年对干流陕西段的调查也得出相似的结 果, 去除引入种后, 共采集到鱼类45种(王丰和沈红 保, 2020), 只占中游鱼类的 $45.45 \%$, 其中鲢、鳙等极 可能是人工增殖放流的结果。黄河下游干流段的情 况同样不乐观，2013年对下游9个断面的调查只发 现了 27 种鱼类, 占下游鱼类总数的 $26.73 \%$ (刘洪波 和菅浩然, 2019)。通过对黄河干流指示性鱼类种群 完整度的分析, 黄河上游指示鱼类完整度指数为 0.43 , 中游段为 0.29 , 下游为 0.11 , 全流域平均为 0.28 , 处于0.21-0.40之间, 可以看出黄河鱼类种群 整体处于严重缺失状态(待发表数据)。

黄河支流也存在类似现象。例如2016-2017年 对渭河的调查显示, 相较于 20 世纪 80 年代调查结果, 鱼类物种数量减少 36 种, 相似度仅为 0.49 , 为中等 不相似, 且物种组成的变化也十分明显(沈红保等, 2019)。2016年在下游最大支流大汶河的调查只发现 鱼类18种, 综合其他因子评价, 大汶河流域水生态 系统健康状况整体处于较差和极差状态(温家华等, 2018)。整体上看, 无论黄河干流还是主要支流, 鱼 类多样性都处于严重衰退当中。

\section{黄河鱼类多样性面临的威胁}

\section{1 水电开发}

1979年全国水力资源普查结果显示, 黄河流域 水力资源理论蕴藏量 $4,054.8$ 万W, 年平均发电量 3,552 亿 $\mathrm{kW} \cdot \mathrm{h}$ ，占全国水力资源理论蕴藏量59,221.8 亿 $\mathrm{kW} \cdot \mathrm{h}$ 的6\%。73.3\%的水力资源分布在黄河干流上， 其中集中分布在上游的玛曲至青铜峡和下游的河 口村至花园口两个河段, 分别占干流的 53.9\%和 $32.1 \%$ 。支流水力资源蕴藏量主要集中在3条主要支 流洮河、湟水和渭河, 这3条支流均在黄河中上游 (http://www.yrcc.gov.cn/hhyl/hhgk/qh/slzy/201108/t2 0110814_103524.html)。在黄河中上游，对于鱼类多 样性产生的最大威胁来自于水力开发。黄河上游以 龙羊峡为界, 龙羊峡(不含)以上按 13 级开发, 梯级 电站总装机容量约792万 $\mathrm{kW}$; 龙羊峡至青铜峡河段 布置了 25 个梯级电站，总装机容量约 1,700 万 $\mathrm{kW}$ (安盛勋, 2004)。中游以禹门口为界, 上段的黄河北 干流将进行至少6级开发，禹门口以下的河段目前 已修建了三门峡和小浪底水利枢纽(丁双跃和郑卫 国, 2002)。

黄河流域共有大、中型水库 219 座, 其中大型 水库 34 座(水利部黄河水利委员会黄河水资源公报, http://www.yrcc.gov.cn/other/hhgb/)。水电站/水库对 于鱼类多样性的影响是多方面的，首先水体从“河 流相”向 “湖泊相”的剧烈转变, 导致适合流水生境 生存的物种退出库区，同时却为很多适合静水生活 的外来物种创造了良好空间 (Paukert \& Galat, 2010)。特别是首尾相连的梯级水库，将使大段河流 的原生环境被彻底改变。例如龙羊峡-刘家峡河段 长约 $420 \mathrm{~km}$, 共规划了 14 座水电站，从上到下依次 为龙羊峡、拉西瓦、尼那、山坪、李家峡、直岗拉 卡、康扬、公伯峡、苏只、黄丰、积石峡、大河家、 炳灵和刘家峡。自 20 世纪 50 年代刘家峡开工建设 以来，除山坪外基本均已建成，是黄河上游已建和 在建水电梯级最为集中的河段。所建电站基本上首 尾相连，使得一些适应流水生境的黄河上、中游特 有裂腹鱼类, 如厚唇裸重唇鱼(VU)、极边扁咽齿鱼 (EN)和骨唇黄河鱼(EN), 已经完全退出龙洋峡-刘 家峡河段。另外，大坝的建设也阻断了河流的纵向 连通性，使得一些洄游性鱼类难以完成生活史。例 如降河产卵的日本鳗鲭(Anguilla japonica), 历史上 可以分布到关中盆地以及晋南洪洞、翼城、新㖓等 地(李思忠, 2015), 但由于三门峡等水库的存在, 目 前在陕西等地的黄河水体已无法发现自然生存的 日本鳗鲡个体(王丰和沈红保, 2020)。

水库对于一些产漂流性卵鱼类的影响更是首 当其冲，在黄河流域最典型的例子就是北方铜鱼 (Coreius septentrionalis)。北方铜鱼是黄河特有鱼类, 青海贵德到山东都曾有分布(李思忠, 2015), 过去一 直是黄河重要的渔业对象。在黄河上游, 青铜峡大 坝建成(1960年截流)后，宁夏河段的北方铜鱼年产 量即从约15 t降至几千斤, 大坝以下河段则几乎绝 迹(何志辉, 1987)。黄河中游小浪底水库建库前, 在 
孟津至郑州河段北方铜鱼繁殖期捕捞量都在 $150 \mathrm{~kg}$ 以上，且多为成熟个体; 然而随着大坝截流(1997 年), 产卵场破坏, 水环境发生改变, 没有足够流水 空间满足北方铜鱼的繁殖需求, 导致北方铜鱼种群 数量迅速下降(郭严军, 2008)。目前该种濒危等级已 从1998年的濒危(EN)提升到极危(CR) (乐佩琦和陈 宜瑜, 1998; 蒋志刚等, 2016)。作者在2007年以后长 时间对黄河鱼类的调查中, 再未发现北方铜鱼。类 似大坝对产漂流性卵鱼类如圆口铜鱼(Coreius guichenoti)的影响, 也显著发生在长江流域(林鹏程 等, 2019b)。

如前所述, 黄河上游在鱼类多样性上的一个特 点就是虽然物种数量不多, 但是黄河特有鱼类、濒 危物种的占比很高, 其中不少种类对环境条件的要 求很高, 分布区又很狭窄, 极易受到水电站/水库的 影响而导致种群大幅衰退, 甚至面临整个物种从地 球上消失的重大生态风险。如何处理好黄河上、中 游特有鱼类的保护与水电开发之间的矛盾, 是关乎 未来黄河流域高质量发展的关键之一。

\section{2 水资源过度利用}

黄河水资源量十分匮乏，其水资源总量仅占全 国的 2.6\% 在全国七大江河中居第 4 位。人均水资 源量 $905 \mathrm{~m}^{3}$, 亩均水资源量 $381 \mathrm{~m}^{3}$, 分别是全国人 均、亩均水资源量的 $1 / 3$ 和 $1 / 5$ 。然而黄河却承载了 全国 $15 \%$ 耕地和 $12 \%$ 人口的供水任务(李文学, 2016), 同时要向流域外区域调水, 为经济社会发展 提供帮助，因此黄河是我国水资源供需矛盾最突出 的流域之一。黄河断流自 1972 年首次出现后逐渐 加剧, 20 世纪 90 年代几乎每年均有发生, 1997 年下 游利津站曾连续断流 226 天。之后经过统一调度黄 河水量, 于 1999 年后实现了连续 20 年不断流(赵勇 等, 2020)。然而黄河流域水资源的供需矛盾并没有 解决, 2018 年黄河总取水量为 516.22 亿 $\mathrm{m}^{3}$, 总耗水 量则为 415.93 亿 $\mathrm{m}^{3}$ (水利部黄河水利委员会黄河水 资源公报, http://www.yrcc.gov.cn/other/hhgb/), 水资 源利用率达到 $80.6 \%$, 远超国际公认的 $40 \%$ 警戒线 (赵钟楠等, 2020)。所以在保证干流不断流的情况下, 主要支流水量开始大幅衰减, 河道缺水问题大范围 向支流扩散。1980-2016 年遥感监测显示, 黄河湿 地面积降幅已达到 12.5\% (赵勇等, 2020)。过去断流 的影响对于黄河下游干流的鱼类更加明显, 目前则 曼延到黄河中下游的一些重要支流。河流断流对一
些定居性鱼类影响更加显著，不但使得适生的水生 环境消失，且因频繁发生在鱼类繁殖期，影响一些 产沉粘性卵鱼类的种群增殖。

\section{3 水域污染}

黄河流域城镇化进程加快，人口聚集，废污水 排放量增加; 加之天然来水减少, 河道稀释自净能 力和纳污能力降低, 使得黄河流域水污染问题比较 突出(王文杰等, 2017)。近年来随着治污力度的不断 加大, 水污染情况得到较大程度的缓解, 黄河流域 水质整体呈逐步改善趋势(吕振豫和穆建新，2017)。

《2018年黄河水资源公报》显示，黄河干流水质较 好, 无 $\mathrm{V}$ 类和劣 $\mathrm{V}$ 类水质河段, IV 类水质河长只占 $2.2 \%$, 集中于潼关断面。然而黄河主要支流的水质 则不容乐观, IV类、 $\mathrm{V}$ 类、劣 $\mathrm{V}$ 类水质河长分别占评 价河长的 $10.7 \%$ 、6.8\%和 $16.1 \%$ 。流域内水功能区达 标率也只有 $63.3 \%$ 。支流通常分布一些适应溪流流 水生境的小型鱼类如花䱻(Hemibarbus maculatus)、 潘氏鳅鮀(Gobiobotia pappenheimi)等，这些鱼类通 常对水质变化比较敏感，严重的水体污染会导致这 些鱼类在局部水域消失。恶劣的水质除了影响鱼类 的正常生理功能外，对受精卵和仔鱼的影响也尤为 明显, 致使种群不能得到及时补充。因此在一些水 污染较严重的水体中，只有一些耐污能力较强的物 种如鲫(Carassius auratus)、麦穗鱼(Pseudorasbora parva)等才能够生存下来, 多样性异常单调。

\section{4 外来物种}

外来物种已逐渐成为威胁黄河全流域鱼类多 样性的重要因素之一。多数外来鱼类是因为水产养 殖而主动引入，其中既有从国外引入的，也有从中 国东部地区或其他水系引入的; 另外有些小型野杂 鱼类，则是伴随引入物种进入到新水体的; 近年来 宗教放生也成为外来种引入的一个重要途径。

在黄河上游段，因水库渔业的发展，20世纪90 年代在龙羊峡、李家峡水库等从丹麦引入了虹鳟 (Oncorhynchus mykiss); 之后又引入了池沼公鱼 (Hypomesus olidus)和大银鱼(Protosalanx chinensis); 高白鲑(Coregonus peled)等则是从俄罗斯引入; 而 麦穗鱼、泥䱊(Misgurnus anguillicaudatus)等则是随 着鲤(Cyprinus carpio)、鲫一起引入的(唐文家等, 2006)。在2005-2010年间对黄河上游茨哈峡至积石 峡段鱼类多样性的调查发现，干流中的外来鱼类多 达21种，其中17种已经能够自然繁殖，相反该河段 
只能采集到16种土著种类(唐文家和何德奎，2013), 外来鱼类的数量已经超过本地物种。中游陕西段调 查发现的外来鱼类也已经达到了至少14种(或品种), 这还不包括诸如克氏原螯虾(Procambarus clarkii)、 拟鳄龟(Chelydra serpentina)等其他外来水生生物 (王丰和沈红保, 2020), 近年来作者在中游的调查还 新发现了原产于欧洲和中亚等地的梭鲇(Lucioperca lucioperca)。此外黄河下游还报道有雀鳝 (Lepidosteus sp.), 应是放生的结果。

根据作者不完全统计, 目前黄河流域至少存在 34 种(或品种)外来鱼类, 其中20种是从国外引进, 14 种是从国内其他水系(或黄河下游引至上游)引入。 外来物种对本地土著鱼类的影响是多方面的，除了 通过竞争、捕食等作用直接影响土著鱼类种群, 还 会携带一些病原体，对土著鱼类产生进一步危害。 此外, 有些物种通过和本地鱼类的杂交, 破坏了原 有野生种群的遗传多样性。例如德国镜鲤(Cyprinus carpio var. specularis)与黄河土著鲤的杂交后代在 流域内已经非常普遍(李芳等, 2008)。此外, 水库生 境进一步放大了某些外来物种的影响, 对上、中游 一些特有鱼类产生严重威胁。目前针对黄河流域严 重的外来物种问题，已经不能局限于引种上的管理, 一方面应该建立外来物种监测体系对其种群数量 和扩散范围进行跟踪, 另一方面应该制定外来物种 控制和土著鱼类复壮预案, 在重点水域通过人工干 预, 减轻外来鱼类带来的不利影响。

\section{5 渔业捕捞}

20世纪50-60年代, 黄河渔业资源丰富, 例如 黄河上游鄂陵湖花斑裸鲤的产量在1960年曾达到 $525 \mathrm{t}$ (唐文家等, 2006)。但自 70年代开始, 黄河鱼类 资源量开始减少，80年代仅及50年代的 $15 \%-20 \%$ (何志辉, 1987)。目前黄河流域渔业资源严重衰退, 过去一些重要资源性鱼类(如北方铜鱼)已经濒临灭 绝, 很多水域的鱼类组成主要以一些广布种甚至外 来种为主, 同时出现鱼类小型化、低龄化的现象。 过度捕捞在历史上曾经对黄河鱼类产生过重要影 响, 但是随着野生渔业资源的衰退, 相较于其他影 响因素, 目前以渔业为目的的捕捞活动对野生鱼类 多样性的影响已不再显著。随着国家进一步推行禁 渔期和禁渔区制度, 相信未来专业的捕捞活动对于 流域鱼类多样性的影响将进一步下降, 但是对于采 用非法渔具渔法进行的偷捕盗捕, 应坚决予以杜
绝。

如果从区域上分析，对黄河上游鱼类多样性影 响最大的是梯级修建的水电站(水库), 以及外来物 种的影响。在这两个因素综合作用下，上游的一些 黄河特有鱼类濒临灭绝，这将是未来流域保护的重 点。中游和下游则主要受到水资源分配不均衡、水 域污染等的影响。支流则受制于小水电、水体污染 等因素。因此未来制定流域鱼类多样性保护方案时, 应分析不同水域的具体威胁, 针对主要矛盾加以解 决。

\section{参考文献}

An SX (2004) A summary of hydropower planning on the upper reach of the Yellow River. Northwest Hydropower, (3), 1-5. (in Chinese with English abstract) [安盛勋 (2004) 黄河上游水电规划综述. 西北水电, (3), 1-5.]

Cai JY (2017) Census Report on Basic Information of Rivers and Lakes in China. China Water \& Power Press, Beijing. (in Chinese) [蔡建元 (2017) 河湖基本情况普查报告. 中 国水利水电出版社, 北京.]

Cai WX, Zhang JJ, Wang SW (2013) Atlas of Fishes in the Yellow River Basin. Northwest Agriculture and Forestry University Press, Yangling. (in Chinese) [蔡文仙, 张建军, 王守文 (2013) 黄河流域鱼类图志. 西北农林科技大学 出版社, 杨凌.]

Cao L, Zhang E, Zang CX, Cao WX (2016) Evaluating the status of China's continental fish and analyzing their causes of endangerment through the red list assessment. Biodiversity Science, 24, 598-609. (in Chinese with English abstract) [曹亮, 张鸣, 藏春金金, 曹文宣 (2016) 通过红色 名录评估研究中国内陆鱼类受威胁现状及其成因. 生物 多样性, 24, 598-609.]

Cheng QT, Zhou CW (1997) The Fishes of Shandong. Shandong Science and Technology Press, Jinan. (in Chinese) [成庆泰, 周才武 (1997) 山东鱼类志. 山东科学 技术出版社, 济南.]

Department of Biology, Shanxi Normal University (1960) Investigation on fisheries biology of the Fenhe River. Journal of Shanxi Normal University, (3), 1-26. (in Chinese) [山西师范学院生物系 (1960) 汾河渔业生物学 基础调查. 山西师范学院学报, (3), 1-26.]

Ding RH (1994) The Fishes of Sichuan. Sichuan Science and Technology Press, Chengdu. (in Chinese) [丁瑞华 (1994) 四川鱼类志. 四川科学技术出版社, 成都.]

Ding SY, Zheng WG (2002) Effects of hydropower development on management of ecological environment in the middle reaches of the Yellow River. China Water Resources, (3)，58，75. (in Chinese) [丁双跃，郑卫国 (2002) 黄河中游水电开发对生态环境治理的作用.中国 
水利, (3), 58, 75.]

Duan ZY, Zhao K, Peng ZG, Li JB, Diogo R, Zhao XQ, He SP (2009) Comparative phylogeography of the Yellow River schizothoracine fishes (Cyprinidae): Vicariance, expansion, and recent coalescence in response to the Quaternary environmental upheaval in the Tibetan Plateau. Molecular Phylogenetics and Evolution, 53, 1025-1031.

Fang PW (1935) On some Nemacheilus fishes of North-Western China and adjacent territory in the Berlina Zoological Museum's collection, with descriptions of two new species. Sinensia, 6, 749-767.

Fish Group and Invertebrate Group, Institute of Zoology, Chinese Academy of Sciences (1959) Preliminary Investigation Report on Fisheries Biology of the Yellow River. Science Press, Beijing. (in Chinese) [中国科学院动 物研究所鱼类组与无脊椎动物组 (1959) 黄河渔业生物 学基础初步调查报告. 科学出版社, 北京.]

Fowler HW (1931) Collection of fresh water fishes obtained chiefly at Tsinan. Peking Natural History Bulletin, 5, 27-31.

Fu TS (1934) Study of the fishes of Pai-Chuan. Bulletin of the Honan Museum, 1, 47-102.

Fu TS, Tchang TL (1933) The study of the fishes of Kaifeng, Part I. Bulletin of the Honan Museum, 1, 1-45.

Günther A (1898) Report on a collection of fishes from Newchwang, North China. Annals and Magazine of Natural History, 7, 257-263.

Guo YJ (2008) Influences of Xiaolangdi Reservior on Coreius septentrionalis and its conservation strategy. Henan Fisheries, (4), 7-8. (in Chinese) [ 郭严军 (2008) 谈小浪底 水库对北方铜鱼生态的影响及对策. 河南水产, (4), 7-8.]

He DK, Sui XY, Sun HY, Tao J, Ding CZ, Chen YF, Chen YY (2020) Diversity, pattern and ecological drivers of freshwater fish in China and adjacent areas. Reviews in Fish Biology and Fisheries, 30, 387-404.

He ZH (1987) Fishery resource research on Yellow River system. Journal of Dalian Fisheries College, (1), 6366. (in Chinese) [何志辉 (1987) 黄河水系渔业资源调查. 大连 水产学院学报, (1), 63-66.]

He ZH, Xie ZH (1986) Fishery Resource of Yellow River System. Liaoning Science and Technology Press, Dalian. (in Chinese) [何志辉, 谢祚浑 (1986) 黄河水系渔业资源. 辽 宁科学技术出版社, 大连.]

Herzenstein S (1888) Fische. In: Wissenschaftliche Resultate der von N. M. Przewalski nach Central-Asien unternommencn Reisen, pp. 91-98. Zoologischer Theil, Wien.

Huang HF, Zheng SC, Jiang XP (1965) Fish investigation in the middle section of the Weihe River. In: Reports and Abstracts Presented at a Meeting Commemorating the 30th Anniversary of the China Zoological Society. Science Press, Beijing. (in Chinese) [黄洪富, 郑士川, 江希平 (1965) 渭 河中段鱼类调查研究. 见: 中国动物学会三十周年学术 讨论会论文摘要汇编. 科学出版社, 北京.]
Jiang LZ, Wang HF (2011) Analysis of areas soil erosion in the development of the hydropower station on upstream of Yellow River. Journal of Shenyang Agricultural University, 42, 470-474. (in Chinese with English abstract) [蒋立哲, 王慧芳 (2011) 黄河上游水电开发对区域水土流失的影 响分析. 沈阳农业大学学报, 42, 470-474.]

Jiang ZG, Jiang JP, Wang YZ, Zhang E, Zhang YY, Li LL, Xie F, Cai B, Cao L, Zheng GM, Dong L, Zhang ZW, Ding P, Luo ZH, Ding CQ, Ma ZJ, Tang SH, Cao WX, Li CW, Hu HJ, Ma Y, Wu Y, Wang YX, Zhou KY, Liu SY, Chen YY, Li JT, Feng ZJ, Wang Y, Wang B, Li C, Song XL, Cai L, Zang CX, Zeng Y, Meng ZB, Fang HX, Ping XG (2016) Red List of China's Vertebrates. Biodiversity Science, 24, 500-551. (in Chinese and in English) [蒋志刚, 江建平, 王 跃招, 张鹗, 张雁云, 李立立, 谢锋, 蔡波, 曹亮, 郑光 美, 董路, 张正旺, 丁平, 罗振华, 丁长青, 马志军, 汤宋 华, 曹文宣, 李春旺, 胡慧建, 马勇, 吴毅, 王应祥, 周开 亚, 刘少英, 陈跃英, 李家堂, 冯祚建, 王燕, 王斌, 李 成, 宋雪琳, 蔡蕾, 蔵春金金, 曾岩, 孟智斌, 方红霞, 平晓 鸽 (2016) 中国脊椎动物红色名录. 生物多样性, 24, 500-551.]

Li F, Zhang JJ, Yuan YF, Feng H, Zhang JY, Yang XZ (2008) Present situation and problems on fish introduction in Yellow River system. Journal of Anhui Agricultural Sciences, 36, 15024-15026. (in Chinese with English abstract) [李芳, 张建军, 袁永锋, 冯慧, 张军燕, 杨兴中 (2008) 黄河流域鱼类引种现状及存在问题. 安徽农业科 学, 36, 15024-15026.]

Li KM, Shen ZX, Ye HY (2012) Fish diversity research and protection measures of Banduo section in Yellow River. Hebei Fisheries, (7), 26-29. (in Chinese with English abstract) [李柯惁, 申志新, 治海云 (2012) 黄河班多段鱼 类多样性初步研究及保护对策. 河北渔业, (7), 26-29.]

Li RQ (1988) The relationship between developments of the Yellow River and the Yongding River, and the evolution of fossil lake of drainage basin in the Cenozoic Era. Journal of Beijing Normal University (Natural Science), (4), 84-93. (in Chinese with English abstract) [李荣全 (1988) 黄河、永定 河发育历史与流域新生代古湖演变间的相互关系. 北京 师范大学学报(自然科学版), (4), 84-93.]

Li RQ (1993) The formation and change of the Yellow River. In: Geomorphic Characteristics and Evolution of China, pp. 52-59. China Ocean Press, Beijing. (in Chinese) [李荣全 (1993) 黄河的形成与变迁. 见: 中国地貌特征与演化, 52-59页. 海洋出版社, 北京.]

Li SZ (1965) Discussion on the fish fauna of the Yellow River. Chinese Journal of Zoology, (5), 217-222. (in Chinese) [李 思忠 (1965) 黄河鱼类区系的探讨. 动物学杂志, (5), 217-222.]

Li SZ (1981) Studies on Zoogeographical Divisions for Fresh Water Fishes of China. Science Press, Beijing. (in Chinese) [李思忠 (1981) 中国淡水鱼类的分布区划. 科学出版社, 北京.] 
Li SZ (1987) Distribution of fishes from Acipenseriformes in China. Chinese Journal of Zoology, 22(4), 35-40. (in Chinese) [李思忠 (1987) 中国鲟形目鱼类地理分布的研 究. 动物学杂志, 22(4), 35-40.]

Li SZ (2015) Fishes of the Yellow River. The Sueichan Press, Keelung. (in Chinese) [李思忠 (2015) 黄河鱼类志. 水产 出版社, 基隆.]

Li WX (2016) Benefits analysis of the Yellow River harnessment and protection in the last 70 years. Yellow River, 38(10), 1-6. (in Chinese with English abstract) [李文 学 (2016) 黄河治理开发与保护 70 年效益分析. 人民黄 河, 38(10), 1-6.]

Lin PC, Li SZ, Qin XC, Cheng WX, Liu HZ (2019a) Pattern of fish diversity and assemblage structure in the middle and lower reaches of the Yiluo River, Yellow River. Journal of Lake Sciences, 31, 482-492. (in Chinese with English abstract) [林鹏程, 李淑贞, 秦祥朝, 程卫习, 刘焕章 (2019a) 黄河伊洛河中下游鱼类多样性及群落结构. 湖泊 科学, 31, 482-492.]

Lin PC, Wang CL, Liu F, Liu M, Liu HZ, Wang XM, Yu J, Zhu X (2019b) Current status and conservation planning of fish biodiversity in the upper Yangtze River basin in the context of hydropower development. Acta Hydrobiologica Sinica, 43(Suppl.), 130-143. (in Chinese with English abstract) [林鹏程, 王春伶, 刘飞, 刘猛, 刘焕章, 王小明, 于江, 朱所 (2019b) 水电开发背景下长江上游流域鱼类 保护现状与规划. 水生生物学报, 43(增刊), 130-143.]

Liu HB, Jian HR (2019) Investigation on fish resources in the lower reaches of the Yellow River. Journal of Anhui Agricultural Sciences, 47(19), 1101 12, 131. (in Chinese with English abstract) [刘洪波, 菅浩然 (2019) 黄河下游 鱼类资源调查研究. 安徽农业科学, 47(19), 110-112, 131.]

Liu YG (1981) Discussion on fishery status and the stock enhancement in the Maqu section of the Yellow River. Freshwater Fisheries, (3), 37-40. (in Chinese) [刘阳光 (1981) 黄河玛曲段渔业现状及其增殖途径的探讨. 淡水 渔业, (3), 37-40.]

Lü LC, Li WL (2012) Geography of China. Science Press, Beijing. (in Chinese) [吕拉昌, 李文翎 (2012) 中国地理. 科学出版社, 北京.]

Lu XP, Fu ZC (2010) General Introduction to Major River Systems in China. China Water \& Power Press, Beijing. (in Chinese) [陆孝平, 富曾慈 (2010) 中国主要江河水系概 览. 中国水利水电出版社, 北京.]

Lü ZY, Mu JX (2017) Study on spatial and temporal evolution feature of water quality in Yellow River basin. Yellow River, 39(4), 66-70, 77. (in Chinese with English abstract) [吕振豫, 穆建新 (2017) 黄河流域水质污染时空演变特 征研究. 人民黄河, 39(4), 66-70, 77.]

Mori T (1928) Freshwater Fishes from Tsi-nan, China, with description of five new species. Japanese Journal of Zoology, 2, 61-72.
Mori T (1929) Addition to the fish fauna of Tsi-nan, China, with descriptions of two new species. Japanese Journal of Zoology, 2, 383-385.

Mori T (1936) Studies on the Geographical Distribution of Freshwater Fishes in Eastern Asia. Keijo Imperial University, Chosen.

Nichols JT (1925) Some Chinese fresh-water fishes. 4. Gudgeons of the genus Coriparieus. 5. Gudgeons of related to the European Gobio gobio. 6. New gudgeons of the genus Gnathopogon and Leucogobio. American Museum Novitates, 181, 1-8.

Nichols JT (1926) Some Chinese fresh-water fishes. 16. Concerning gudgeons related to Pseudogobio and two new species of it. 17. Two new rhodeins. American Museum Novitates, 214, 1-7.

Pappenheim P (1908) Pisces. In: Filchner Wissenschaftliche Ergebnisse der Expedition Filchner nach China und Tibet (1903-1905). Jena, 10, 107-124.

Paukert CP, Galat DL (2010) Warmwater rivers. In: Inland Fisheries Management in North America (3rd edn), pp. 699-730. American Fisheries Society, Bethesda.

Quan Q, Wang Y, Tian KD, Wu ZG (2018) Impact of hydraulic projects on indigenous fish and its protection in the upper reaches of Yellow River. Environmental Impact Assessment, 40(6), 63-66. (in Chinese with English abstract) [权全, 王炎, 田开迪，武志刚 (2018) 黄河上游 羊曲水电站对土著鱼类的影响与保护. 环境影响评价, 40(6), 63-66.]

Ru HJ, Wang HJ, Zhao WH, Shen YQ, Wang Y, Zhang XK (2010) Fishes in the mainstream of the Yellow River: assemblage characteristics and historical changes. Biodiversity Science, 181, 179-186. (in Chinese with English abstract) [茹辉军, 王海军, 赵伟华, 沈亚强, 王 勇, 张晓可 (2010) 黄河干流鱼类群落特征及其历史变 化. 生物多样性, 181, 179-186.]

Sauvage HÉ, Dabry de Thiersant CP (1874) Notes sur les poissons des eaux douces de Chine. Annales des Sciences Naturelles, Paris (Zoologie et Paléontologie), (Sér. 6), 1, 1-18.

Shaanxi Institute of Zoology, Institute of Hydrobiology of the Chinese Academy of Sciences, Department of Biology of Lanzhou University (1987) Fishes in Qinling Mountains Area. Science Press, Beijing. (in Chinese) [陕西省动物研究 所, 中国科学院水生生物研究所, 兰州大学生物系 (1987) 秦岭鱼类志. 科学出版社, 北京.]

Shen HB, Li RJ, Lü BB, Zhang JY, Yin XW, Wang YC, Wang ZQ, Wang F (2019) Characteristics of fish community structure in the Weihe River of Shaanxi section. Acta Hydrobiologica Sinica, 43, 1311-1319. (in Chinese with English abstract) [沈红保, 李瑞娇, 吕涁涁, 张军燕, 殷旭 旺, 王益昌, 王忠乾, 王丰 (2019) 渭河陕西段鱼类群落 结构组成及变化研究. 水生生物学报, 43, 1311-1319.]

Shen ZX, Wang GJ, Li KM, Jian SL, Chen YQ, Guan HT 
(2014) The situation and protection measures of fish resources in upstream of Longyang Valley of the Yellow River. Journal of Hydroecology, 35(1), 70-76. (in Chinese with English abstract) [申志新, 王国杰, 李柯惁, 简生龙, 陈燕琴, 关弘㢷 (2014) 黄河龙羊峡上游鱼类资源现状 及保护对策. 水生态学杂志, 35(1), 70-76.]

Song SL, Wang XT (1983) Notes on fishes fauna of the upper reaches of Weihe River in China. Journal of Lanzhou University (Natural Sciences), 19(4), 120-128. (in Chinese) [宋世良, 王香亭 (1983) 渭河上游鱼类区系研究. 兰州 大学学报(自然科学版), 19(4), 120-128.]

Tang WJ, He DK (2013) Fish resource survey on Cihaxia to Jishixia stretches in the upper reaches of Yellow River (2005-2010). Journal of Lake Sciences, 25, 600-608. (in Chinese with English abstract) [唐文家, 何德奎 (2013) 黄 河上游茨哈峡至积石峡段鱼类资源调查(2005-2010年). 湖泊科学, 25, 600-608.]

Tang WJ, Shen ZX, Jian SL (2006) Endangered and rare fish species of the Yellow River in Qinghai Province and their conservation strategy. Reservoir Fisheries, 26(1), 57-60. (in Chinese) [唐文家, 申志新, 简生龙 (2006) 青海省黄河珍 稀濒危鱼类及保护对策. 水利渔业, 26(1), 57-60.]

Tchang TL (1932a) A new fish from Kaifeng. Bulletin of the Fan Memorial Institute of Biology, 3, 211-217.

Tchang TL (1932b) Some Chinese cyprinoid fish synonyms (I). Bulletin of the Fan Memorial Institute of Biology, 3, 237-251.

Tchang TL (1933) The study of Chinese cyprinoid fishes, part I. Zoologia Sinica (B), 2, 1-247.

Tchang TL (1941) List of fishes from Ho-nan. Peking Nature and History Bulletin, 16, 79-84.

Tsao WS, Tun CL (1962) Notes on the Schizothoracid fishes from western Szechwan and adjacent territory. Acta Hydrobiologica Sinica, (2), 27-50. (in Chinese) [曹文宣, 邓中麟 (1962) 四川西部及其邻近地区的裂腹鱼类. 水 生生物学集刊, (2), 27-50.]

Tsao WS, Wu HW (1962) An investigation of the fish biology and fishery problems in Ganzi-Apa region of western Szechwan Province. Acta Hydrobiologica Sinica, (2), 79-110. (in Chinese) [曹文宣, 伍献文 (1962) 四川西部 甘孜阿坝地区鱼类生物学及渔业问题. 水生生物学集刊, (2), 79-110.]

Wang F (2020) Conservation status and suggestions on the fishery environment of the Yellow River. China Fisheries, (1), 47-50. (in Chinese) [王丰 (2020) 黄河渔业生态环境 保护现状及建议. 中国水产, (1), 47-50.]

Wang F, Shen HB (2020) Evaluation on Fishery Resources of the Shaanxi Section of the Yellow River. Northwest Agriculture and Forestry University Press, Yangling. (in Chinese) [王丰, 沈红保 (2020) 黄河陕西段渔业资源评 价. 西北农林科技大学出版社, 杨凌.]

Wang J, Zhang CL, Xue Y, Ren YP, Xu BD (2018) Taxonomic diversity of fish community in the Yellow River Estuary.
Acta Oceanologica Sinica, 40(4), 86-95. (in Chinese with English abstract) [王娇, 张崇良, 薛芗, 任一平, 徐宾铎 (2018) 黄河口鱼类群落分类学多样性的研究. 海洋学报, 40(4), 86-95.]

Wang SM, Wu XH, Zhang ZK, Jiang FC, Xue B, Tong GB, Tian GQ (2001) Environment change and eastward flow of the Yellow River based on the sedimentary records of Sanmen ancient lake. Science in China (Series D), 31, 760-768. (in Chinese) [王苏民, 吴锡浩, 张振克, 蒋复初, 薛滨, 童国榜, 田国强 (2001) 三门古湖沉积记录的环境 变迁与黄河贯通东流研究. 中国科学(D辑), 31, 760-768.]

Wang WJ, Jiang WG, Fang Z, Wang W, Guo QZ (2017) Ten-year Change of Ecological Environments in the Yellow River Basin. Science Press, Beijing. (in Chinese) [王文杰, 蒋卫国, 房志, 王维, 国巧真 (2017) 黄河流域生态环境 十年变化评估. 科学出版社, 北京.]

Wang XT, He RL, Zhao HM (1956) Fishes of the Yellow River near Lanzhou. Bulletin of Biology, (8), 14-19. (in Chinese) [王香亭, 贺汝良, 赵宏谟 (1956) 兰州附近黄河的鱼类. 生物学通报, (8), 14-19.]

Wang YC, Shen HB, Zhang JY, Chen YY, Yu B (2017) Species composition and community diversity of fishes in Shaanxi section of Yellow River mainstream. Freshwater Fisheries, 47(1), 56-60. (in Chinese with English abstract) [王益昌, 沈红保, 张军燕, 陈媛媛, 余斌 (2017) 黄河干 流陕西段鱼类种类组成及群落多样性. 淡水渔业, 47(1), 56-60.]

Wen JH, Xu ZH, Wu W, Qi ZH (2018) Study on water ecosystem evaluation in Dawen River Basin. South-to-North Water Transfers and Water Science and Technology, 16(3), 118-124. (in Chinese with English abstract) [温家华, 徐征 和, 武玮, 祁泽慧 (2018) 大汶河流域水生态系统健康评 价研究. 南水北调与水利科技, 16(3), 118-124.]

Wu YF, Chen Y (1979) Notes on fishes from Golog and Yushu region of Qinghai Province, China. Acta Zootaxonomica Sinica, 4, 287-296. (in Chinese with English abstract) [武云 飞, 陈瑗 (1979) 青海省果洛和玉树地区的鱼类. 动物分 类学报, 4, 287-296.]

Wu YF, Wu CZ (1989) Economical Animals of Qinghai: Pisces. Qinghai People's Publishing House, Xining. (in Chinese) [武云飞, 吴翠珍 (1989) 青海经济动物志: 鱼 纲. 青海人民出版社, 西宁.]

Xing YC, Zhang CG, Fan EY, Zhao YH (2016) Freshwater fishes of China: Species richness, endemism, threatened species and conservation. Diversity and Distributions, 22, 358-370.

Xu JX, Shi CX, You LY (2013) Fluvial geomorphology. In: Geomorphology of China, pp. 113-187. Science Press, Beijing. (in Chinese) [许炣心, 师长兴, 尤联元 (2013) 河 流地貌. 见: 中国地貌, 113-187页. 科学出版社, 北京.]

Xu RG (2013) Fauna Inner Mongolia (Volume 1): Cyclostomata, Pisces. Inner Mongolia University Press, Huhhot. (in Chinese) [旭日干 (2013) 内蒙古动物志(第一 
卷): 圆口纲, 鱼纲. 内蒙古大学出版社, 呼和浩特.]

Yang BH, Ma SQ, Wang M, Xu ZX, Yin XW (2019) Relationship between fish community and environmental factors in Jinan region in autumn. Chinese Journal of Fisheries, 32(3), 34-38. (in Chinese with English abstract) [杨柏贺, 马思琦, 王汨, 徐宗学, 殷旭旺 (2019) 秋季济 南地区鱼类群落结构及其与环境因子的关系. 水产学杂 志, 32(3), 34-38.]

You LY, Yang JC (2013) Geomorphology of China. Science Press, Beijing. (in Chinese) [尤联元, 杨景春 (2013) 中国 地貌. 科学出版社, 北京.]

Yue PQ, Chen YY (1998) China Red Data Book of Endangered Animals: Pisces. Science Press, Beijing. (in Chinese) [乐佩 琦, 陈宜瑜 (1998) 中国濒危动物红皮书: 鱼类. 科学出 版社, 北京.]

Zhang CG, Zhao YH (2016) Species Diversity and Distribution of Inland Fishes in China. Science Press, Beijing. (in Chinese) [张春光, 赵亚辉 (2016) 中国内陆鱼类物种与 分布. 科学出版社, 北京.]

Zhang LS, Ye Y, Zeng ZZ (2012) Changes of river systems and formation of natural geographical environments of three major plains in the east of China. In: China's Palaeogeography: The Formation of Natural Geographical Environments, pp. 306-366. Science Press, Beijing. (in Chinese) [张兰生, 叶瑜, 曾早早 (2012) 江河水系演化与 东部三大平原自然地理环境的形成. 见: 中国古地理-中 国自然环境的形成, 306-366页. 科学出版社, 北京.]

Zhang YP, Lou ZY, Wang T, Du YY, Jiao WL (2013) Population genetic diversity of Triplophysa siluroides in Maqu section in upper reaches of Yellow River. Freshwater Fisheries, 43(6), 86-89. (in Chinese with English abstract) [张艳萍, 娄忠玉, 王太, 杜岩岩, 焦文龙 (2013) 黄河玛 曲段似鲇高原鳅的种群遗传多样性. 淡水渔业, 43(6), 86-89.]
Zhao KT (1963) A survey of the fishes of the Hoh-hot, Inner Mongolia. Journal of Inner Mongolia University (Natural Science), (1), 63-69. (in Chinese with English abstract) [赵 肯堂 (1963) 呼和浩特的鱼类调查. 内蒙古大学学报(自 然科学), (1), 63-69.]

Zhao RL, Zhu GQ, Hu ZP, Li LH (2014) Fish composition and distributions of spawning ground, nursery ground and wintering ground in Shanxi section of the mainstream Yellow River. Chinese Journal of Fisheries, 27(3), 6-11. (in Chinese with English abstract) [赵瑞亮, 朱国清, 胡振平, 李利红 (2014) 黄河干流山西段鱼类组成及其产卵场、索 饵场和越冬场分布的调查. 水产学杂志, 27(3), 6-11.]

Zhao Y, He F, He GH, Li HH, Wang LZ, Chang HY, Zhu YN (2020) Review the phenomenon of Yellow River cutoff from a whole perspective and identification of current water shortage. Yellow River, 42(4), 42-46. (in Chinese with English abstract) [赵勇, 何凡, 何国华, 李海红, 王丽珍, 常英宇，朱永楠 (2020) 全域视角下黄河断流再审视与 现状缺水识别. 人民黄河, 42(4), 42-46.]

Zhao ZN, Zhang Y, Li YY, Yuan Y, Tian Y (2020) Preliminary thoughts on the supports of water conservancy for ecological conservation and high-quality development in the Yellow River basin. Water Resources Planning and Design, (2), 1-3. (in Chinese) [赵钟楠, 张越, 李原园, 袁勇, 田英 (2020) 关于黄河流域生态保护与高质量发展水利支撑保障的初 步思考. 水利规划与设计, (2), 1-3.]

Zhu SQ (1992) Three new species of Nemacheilinae fishes from China (Cypriniformes: Cobitidae). Acta Zootaxonomica Sinica, 17, 241-247. (in Chinese with English abstract) [朱 松泉 (1992) 中国条鳅亚科鱼类三新种(鲤形目: 鳅科). 动物分类学报, 17, 241-247.]

(责任编委：陈小勇 责任编辑：时意专) 